Monika Nawrocka-Theus

(Biblioteka Uniwersytecka, Uniwersytet im. Adama Mickiewicza w Poznaniu)

\title{
Pierwsze lata wolności w Teatrze Polskim w Poznaniu (1918-1924)
}

Rok 1918 - przełomowy dla historii Polski i Poznania stał się również takim dla Teatru Polskiego. Zmiany organizacyjno-administracyjne, których początki sięgają owego czasu, okazały się znaczące dla jego dalszego rozwoju, a nie byłyby możliwe, gdyby w Poznaniu nie „wybuchła” Polska, jak się wtedy mówiło. Ich owocem są lata 1920-1924 będące jednym z najciekawszych okresów historii Teatru Polskiego.

Od $1914 \mathrm{r}$. teatr poznański działał w wyjątkowo trudnych warunkach. I wojna światowa przerwała dyrekcję Bolesława i Nuny Szczurkiewiczów i nie pozwoliła im powrócić do Poznania po wakacyjnej przerwie. Od 1914 r. pomniejszony zespół teatralny działał jako Teatr w Domu Królowej Jadwigi pod kierownictwem Celestyna Rydlewskiego ${ }^{1}$. W 1916 r. grupa aktorów działała pod kierownictwem Bogumiła Bieczyńskiego w dawnym gmachu przy ul. Berlińskiej. Bieczyński sprawował kierownictwo tylko nad zespołem artystycznym, a odpowiedzialność finansową za teatr ponosiła Spółka Teatralna Teatr Polski w Ogrodzie Potockiego w Poznaniu. Warunki wojenne i brak fachowego artystycznego kierownictwa (Bieczyński był przed wojną dyrektorem administracyjnym) sprawiły, że lata 1916-1918 zostały uznane za okres największego upadku Teatru Polskiego ${ }^{2}$.

Początkiem nadchodzących zmian w działalności Teatru Polskiego był kwiecień $1918 \mathrm{r}$. W poznańskiej prasie zaczęły się wtedy ukazywać wzmianki i informacje o przyszłej zmianie dyrekcji teatru. W „Kurierze Poznańskim”

${ }^{1}$ E. Baniewicz, Teatr poznański w latach 1908-1918, [w:] Dzieje teatru polskiego, red. T. Sivert, t. IV, Teatr polski w latach 1890-1918, Warszawa, 1987, s. 377-378.

2 Tamże, s. 381. 
z 23 kwietnia 1918 r. czytamy: „Pan B. Szczurkiewicz, dyrektor teatru naszego. [...] przybył w sobotę do Poznania, aby objać na nowo dyrekcję teatru"3. Gazeta podała jeszcze, że powrót Nuny Młodziejowskiej-Szczurkiewiczowej „bawiącej obecnie we Lwowie” nastąpi za dziesięć-czternaście dni, po załatwieniu formalności paszportowych. Warto $\mathrm{w}$ tym miejscu poświęcić uwage małżeństwu Szczurkiewiczów, których nazwisko nie było Poznaniowi obce.

Bolesław Szczurkiewicz urodził się w 1875 r. we Lwowie. Ukończył szkołę dramatyczną Emila Derynga w Warszawie w roku 1895. Debiutował na scenie w wędrownych teatrach w 1894 r. w Galicji. W latach 1895-1905 występował w: Stanisławowie, Krynicy, Łodzi, w warszawskim teatrze Bagatela, teatrze krakowskim i dwukrotnie w teatrze poznańskim - w latach 1899-1901 i w sezonie 1904/05. W 1908 r. poślubił Nunę Młodziejowską - aktorkę i dyrektorkę teatru wileńskiego - i od tego roku razem z nią prowadził tę scenę do roku 1910. Okres ten zaliczany jest do chlubnych w okresie wileńskiego teatru. Po dwuletniej pracy $w$ teatrze krakowskim wraz z żoną objął dyrekcję w poznańskim Teatrze Polskim, sprawując ją przez dwa sezony (1912/13, 1913/14), aż do wybuchu I wojny światowej ${ }^{4}$.

Nuna Młodziejowska urodziła się w 1884 r. w Żytomierzu. Zawodu aktorskiego uczyła się u Wandy Siemaszkowej w Krakowie, w Klasie Dramatycznej przy Warszawskim Towarzystwie Muzycznym, i u Marii Przybyłko-Potockiej. Debiutowała w Teatrze Miejskim w Krakowie w 1903 r. i grała tam przez jeden sezon 1903/04. Następny 1904/ 05 spędziła w teatrze poznańskim. W 1906 r. objęła dyrekcję teatru wileńskiego, restytuując go z własnych funduszy (teatr wileński był zamknięty od 1864 r.). W 1908 r. poślubiła aktora Bolesława Szczurkiewicza i do roku 1910 razem z nim prowadziła scenę wileńską, podnosząc znacznie jej poziom artystyczny. Trudności finansowe sprawiły, że oboje musieli ustąpić z dyrekcji. W latach 1910-1912 występowała w Teatrze im. Słowackiego w Krakowie. W sezonach 1912/13 i 1913/14 wraz mężem prowadziła scenę poznańską ${ }^{5}$.

Czasy dyrekcji Nuny i Bolesława Szczurkiewiczów w latach 1912-1914 zostały uznane za okres renesansu Teatru Polskiego. Ich dyrekcję z tych lat uznaje się za przełomową dla poznańskiej sceny. Szczurkiewiczowie zmienili charakter pracy aktorów, wprowadzili stałą reżyserię, a przede wszystkim zadbali o repertuar, mając prawdopodobnie zamiar uczynić z Poznania miasto prapremier polskiej dramaturgii współczesnej ${ }^{6}$. Ich pracę przerwał

3 „Kurier Poznański” 1918, nr 93 , s. nlb.

4 Stownik biograficzny teatru polskiego 1765-1965, red. Z. Raszewski, Warszawa 1973, s. 703.

5 Tamże, s. 450.

${ }^{6}$ M.K. Maciejewska, Teatr Polski w Poznaniu w latach 1912-1914, [w:] Prace o literaturze $i$ teatrze ofiarowane Zygmuntowi Szweykowskiemu, pod red. S. Furmanik, Wrocław 1966, s. 596; E. Guderian-Czaplińska, Teatralna Arkadia. Poznańskie teatry dramatyczne 1918-1939, Poznań 2004, s. 34 . 
wybuch I wojny światowej. Wojna zastała ich na wakacjach, które spędzali na Wołyniu, i powrót do Poznania okazał się niemożliwy. Kiedy tylko jednak $\mathrm{z}$ „Zachodu zaczęły nadchodzić interesujące wieści”, podjęli starania, aby wrócić do Poznania ${ }^{7}$. Pierwszy - jak wynika z przytoczonych notatek - przybył tu Bolesław Szczurkiewicz w kwietniu 1918 r.

Warunkiem objęcia dyrekcji Teatru Polskiego przez Bolesława Szczurkiewicza było uregulowanie formalności związanych z zarządzaniem teatrem. Teatr Polski od jego założenia był prywatnym przedsiębiorstwem. Właścicielem gmachu i wyposażenia teatru była Spółka Teatralna Teatr Polski w Ogrodzie Potockiego w Poznaniu, powstała w 1871 r. W jej gestii leżał wybór dyrektora oraz ustalenie zasad działania teatru pod jego kierownictwem. Najczęściej stosowano zasadę tzw. antrepryzy, czyli zatrudniano dyrektora, który: lokował w przedsiębiorstwo swój kapitał, przejmował ryzyko finansowe, sam angażował aktorów, zawierając z nimi umowy, i od Spółki dzierżawił gmach na określonych zasadach. Tylko dwa razy Spółka prowadziła teatr na własny rachunek - w latach 1883-1896 i 1916-1918. W momencie, w którym Szczurkiewiczowie przyjechali do Poznania, właśnie na takiej zasadzie kierownictwo nad teatrem sprawował Bogumił Bieczyński.

Nuna Młodziejowska-Szczurkiewiczowa pisze w swoich wspomnieniach: „Bardzo szybko doszliśmy do porozumienia ze »Spółką Teatralną i otrzymaliśmy z jej rąk »klucze« do prowadzenia teatru" ${ }^{\prime \prime}$. Wydaje się, że rzeczywiście decyzja o zmianie dyrekcji teatru nie była dla Spółki trudną. Szczurkiewiczowie sprawowali przecież dyrekcję nad Teatrem Polskim i zyskali w Poznaniu duże uznanie. Dwa przedwojenne sezony, które przygotowywali, uznane zostały za renesans sceny. Z notatek poznańskiej prasy informujących o ich powrocie przebija ogromna radość i oczywiste przekonanie, że Szczurkiewiczowie obejmą znowu dyrekcję Teatru Polskiego. W „Kurierze Poznańskim" ukazywały się następujące notki: „Teatr nasz odzyskał wreszcie swego ojca, [...] skończył się wreszcie smutny aż nadto okres sieroctwa sceny poznańskiej. Wierzymy bowiem, że obok kierownictwa w doświadczonym ręku p. Szczurkiewicza spocznie także reżyseria. A to już posiada znaczenie równorzędne. [...] Powrotu jego, jak i dzielnej towarzyszki jego, p. Nuny Młodziejowskiej, oczekiwaliśmy od dawna z upragnieniem, [...] czasy dyrekcji obojga przed wojną to najpiękniejsza karta w historii teatru poznańskiego. Ogół nasz czasy te ma we wdzięcznej pamięci i dlatego też wiadomość dzi-

\footnotetext{
${ }^{7}$ N. Młodziejowska-Szczurkiewiczowa, Kartki z niedokończonego pamiętnika, [w:] Poznańskie wspominki. Starzy poznaniacy opowiadaja, Poznań 1960, s. 248-249.

${ }^{8}$ M. Witkowski, Teatr w Poznaniu 1863-1896, w: Dzieje teatru, t. III, Teatr polski od 1863 do schyłku XIX wieku, Warszawa 1982, s. 642; E. Baniewicz, dz. cyt., s. 379-381; Z. Raszewski, Krótka historia teatru polskiego, Warszawa 1978, s. 81.

${ }^{9}$ N. Młodziejowska -Szczurkiewiczowa, dz. cyt., s. 249.
} 
siejszą z najwyższą przyjmujemy radością"10. Podobnej treści notki ukazały się z okazji pierwszego występu Szczurkiewiczów (zanim objęli dyrekcję gościnnie reżyserowali i występowali na poznańskiej scenie Bieczyńskiego). Premiera Panny Mężatki 6 czerwca 1918 r. była sukcesem artystycznym dyrektorskiej pary i zarazem powitaniem ich w Poznaniu. Na premierze zjawiła się bardzo licznie publiczność, „,były niemilknące owacje, była powódź kwiatów, która zalała scenę całą"11.

Poznańska prasa i publiczność nie kryła więc ogromnej sympatii i uznania dla Nuny i Bolesława Szczurkiewiczów. Przypuszczalnie notki tej treści były odbiciem nastrojów, które ogarnęły środowisko teatralne i samą Spółkę. Przypomnijmy, że w momencie przyjazdu Szczurkiewiczów Teatr Polski działający pod kierownictwem artystycznym Bieczyńskiego, który nie był dobrym fachowcem $\mathrm{w}$ tej dziedzinie, znajdował się $\mathrm{w}$ stanie największego upadku. Poznańska prasa nie kryła, że okres jego kierownictwa uznawany jest za przejściowy. Objęcie dyrekcji przez znaną dyrektorską parę wydawało się dla wszystkich sprawą oczywistą.

Jak już wspomniałam powyżej, warunkiem objęcia dyrekcji Teatru Polskiego było uregulowanie formalności ze Spółką. W piśmie do „Kuriera Poznańskiego" od dyrekcji Teatru Polskiego Towarzystwa Akcyjnego, podpisanym przez dr. Bolesława Krysiewicza, Karola Sczanieckiego i Franciszka Rynarzewskiego czytamy: „Po powrocie pp. Szczurkiewiczów do Poznania przeszło kierownictwo naszej sceny na mocy swego czasu zawartego kontraktu końcem sierpnia t.r. w ich ręce" ${ }^{\prime 12}$. Istnieje dokument z 8 sierpnia 1925 roku, który powołuje się na zawarty w 1918 r. kontrakt między Spółką a Bolesławem Szczurkiewiczem. Jest to pismo wiceprezydenta miasta do Spółki Akcyjnej Teatr Polski w sprawie zwolnienia Magistratu od opłacania dzierżawy. Wynika z niego jednoznacznie, że kontrakt dzierżawy gmachu Teatru Polskiego został zawarty między Spółką a Szczurkiewiczem i przewidywał opłacanie czynszu dzierżawnego po pięć proc. od przychodu brutto ze sprzedaży biletów ${ }^{13}$. W sierpniu 1918 r. prasa doniosła: „Zarząd Teatru Polskiego przechodzi - jak się dowiadujemy - z dniem 20 sierpnia pod wyłączny kierunek dyr. N. i B. Szczurkiewiczów"14. Ostatnie przedstawienie zespołu pod kierownictwem Bogumiła Bieczyńskiego odbyło się 19 sierpnia 1918 r. ${ }^{15}$

Z przytoczonych powyżej dokumentów wynika, że Bolesław Szczurkiewicz po przyjeździe do Poznania zawarł umowę ze Spółką Akcyjną Teatr Polski w Ogrodzie Potockiego w Poznaniu, na podstawie której dzierżawił

\footnotetext{
10 „Kurier Poznański” 1918, nr 93, s. nlb.

11 „Kurier Poznański” 1918, nr 129, s. nlb.

12 „Kurier Poznański” 1918, nr 223, s. nlb.

13 APP, AmP, nr 3567, k. 132.

14 „Kurier Poznański” 1918, nr 188, s. nlb.

15 „Kurier Poznański” 1918, nr 190, s. nlb.
} 
od niej budynek, a sam przejmował całkowitą odpowiedzialność za działanie Teatru Polskiego. Dyrekcję nad teatrem przejął 20 sierpnia 1918 r. po ustępującym Bieczyńskim. Sprawował nad nią kierownictwo aż do 1930 r. ${ }^{16}$ Był jednym z niewielu dyrektorów w polskich teatrach, tak długo obejmującym kierownicze stanowisko w jednym teatrze. Dwanaście lat nieprzerwanej - mimo wielu trudności - dyrekcji może świadczyć o tym, jak dobrym był administratorem i kierownikiem.

Potwierdzenie dobrego kierownictwa nad zespołem pracowników teatru można znaleźć w licznych wspomnieniach ludzi teatru z tamtego okresu. Szkic o Szczurkiewiczu napisał po jego śmierci Witold Noskowski - krytyk teatralny. Podkreślił w nim przede wszystkim charakter dyrektora, „,człowieka dobrego, miłego, dającego się lubić i lubianego, w ogóle kogoś bliskiego". Niewątpliwie miało to bardzo dobry wpływ na współpracę dyrektora z podległym mu zespołem aktorskim. Wszyscy, zarówno ci „sprzed budki suflera, jak i krzeseł recenzenckich", mówili o Szczurkiewiczu - Bolek. "Jestem pewien - pisał Noskowski - że niełatwo znaleźć drugiego takiego dyrektora, który by tak jak Szczurkiewicz umiał zażegnywać burze i swym spokojem uspokajać innych uczestników tej awantury w permanencji, którą nazywamy teatrem"17. Najważniejszym jednak źródłem dobrej atmosfery w Teatrze Polskim w Poznaniu były dobre warunki dla artystycznej pracy, które dyrekcja zapewniała aktorom. Brak „zapiekłych nienawiści do dyrekcji i walki na śmierć i życie” w zespole były - zdaniem Adama Grzymały-Siedleckiego wynikiem pracy teatru Szczurkiewicza, w którym bardzo szybko następowały zmiany w repertuarze. Premiery odbywały się często, dając wiele pracy artystom i możliwość „wygrania się do syta”. Grzymała-Siedlecki wspomina: „Rzeczą było znaną, że ówczesny teatr poznański przywiązywał do siebie pracowników zarówno technicznych, jak i artystycznych. Przynajmniej połowa aktorów siedziała tu latami"18.

Omawiając dyrekcję Teatru Polskiego po odzyskaniu wolności, nie można ominąć roli żony Bolesława Szczurkiewicza - Nuny Młodziejowskiej. Podobno w jedno zrastały się dwa te nazwiska. Mimo iż formalnie dyrektorem Teatru Polskiego był Bolesław Szczurkiewicz - to on podpisywał kontrakt ze Spółką - zawsze mówiło się o dyrektorskiej parze, o Szczurkiewiczach ${ }^{19}$. Nuna Młodziejowska cieszyła się dużą sympatią publiczności jako aktorka. Jerzy Koller - krytyk teatralny związany z Poznaniem w okresie międzywojennym, znający ją osobiście, napisał o niej po latach: „Całe życie tej kobie-

\footnotetext{
${ }^{16}$ APP, AmP, nr 3606, k. 34.

17 W. Noskowski, Trochę wspomnień o Szczurkiewiczu, „Kurier Poznański.” 1933, nr 443, s. 8.

18 A. Grzymała-Siedlecki, Świat aktorski moich czasów, Warszawa 1957, s. 215.

19 Tamże, s. 212.
} 
ty koncentrowało się na jednym słowie - teatr. [...] Jako dyrektorka teatru w Poznaniu pierwsza przychodziła do teatru i ostatnia zeń wychodziła"20.

Bolesław i Nuna Szczurkiewiczowie tworzyli jedną z najbardziej znanych małżeńskich dyrektorskich par w Polsce. Panowała pomiędzy nimi swoista harmonia i zrozumienie. Jerzy Koller w swoich Gawędach teatralnych napisał: „Dyrektorowa reprezentowała polot i fantazję, a dyrektor Szczurkiewicz zdrowy rozsądek, liczący się z prozaicznymi, materialnymi, ale i nieuniknionymi postulatami teatru" 21 .

Bolesław Szczurkiewicz sprawował dyrekcję przy pomocy żony do $1933 \mathrm{r}$. Spółka w tymże roku nie odnowiła z nim kontraktu prawdopodobnie ze względu na stan jego zdrowia ${ }^{22}$. Wkrótce potem zmarł w Zakopanem (23 września 1933 r.). Nuna Młodziejowska umarła 23 stycznia 1958 r. w Poznaniu ${ }^{23}$.

Z perspektywy lat okazało się, żezmiana dyrekcji w sierpniu 1918r.przyniosła zmianę w pozycji Teatru Polskiego. Wielką zasługą dyrekcjiSzczurkiewicza były ciągłe starania o podwyższenie poziomu Teatru Polskiego. Dyrektor odbywał liczne podróże w celu angażowania dobrego zespołu aktorskiego, reżyserów czy wreszcie nowości repertuarowych. Od czasu drugiego przejęcia sceny poznańskiej przez małżeństwo Szczurkiewiczów teatr ten zaczął się liczyć w ogólnopolskim życiu teatralnym. Zmiana, która nastąpiła w 1918 roku, u progu wolności miała zaowocować rozwojem teatralnej sceny w Poznaniu.

Szczurkiewiczowie rozpoczęli nowy sezon mimo trudnych warunków wojennych. W „Kurierze Poznańskim” pisano: „P. dyr. Szczurkiewicza czeka obecnie praca istotnie bardzo wielka, w swych zamierzeniach reorganizacyjnych natrafi na niejedną poważną trudność, którą będzie musiał w imię dobra sprawy przezwyciężyć z konsekwencją żelazną"24. Warto przyjrzeć się ich pracy w organizacji teatru, której owocem był sezon 1918/19, rozpoczęty jeszcze w zaborze pruskim, a zakończony już w wolnej Polsce.

Dyrektorska para po powrocie do Poznania od razu rozpoczęła pracę w teatrze. Nuna i Bolesław Szczurkiewiczowie gościnnie występowali na scenie Bogumiła Bieczyńskiego, a przyszły dyrektor również reżyserował. Ich pojawienie się $\mathrm{w}$ teatrze ożywiło życie teatralne miasta. Jednocześnie rozpoczęli przygotowania do otwarcia nowego sezonu 1918/19.

Pierwszym przedsięwzięciem podjętym przez nową dyrekcję było powiększenie zespołu aktorskiego Teatru Polskiego poprzez zaangażowanie znanych i dobrych artystów. Liczniejsza i lepsza grupa aktorska zapewniała możliwość wystawiania sztuk o wyższym poziomie artystycznym oraz wyższą frekwencję. Do teatru przyciągają publiczność oprócz repertuaru właśnie

\footnotetext{
${ }^{20}$ J. Koller, Nuna Młodziejowska-Szczurkiewiczowa, "Gazeta Poznańska” 1958, nr 27, s. 2.

21 Tamże.

${ }^{22}$ W. Noskowski, dz. cyt., s. 8.

23 Stownik biograficzny teatru polskiego, s. 450, 703.

24 „Kurier Poznański” 1918, nr 93, s. nlb.
} 
dobrzy aktorzy, którzy stają się ulubieńcami widowni. Skompletowanie dobrego zespołu aktorskiego zawsze sprawiało trudności dyrektorom poznańskiej sceny. W teatralnym środowisku wszystko poza Warszawą, Krakowem i Lwowem uchodziło za prowincję. Poznański teatr nie cieszył się wielkim uznaniem i jako taki nie przyciągał dobrych aktorów. Jeżeli natomiast aktor zdecydował się na angaż w teatrze poznańskim, to po jednym sezonie musiał go opuścić. Przepis władz pruskich bowiem nie pozwalał aktorom nie będącym obywatelami pruskimi przebywać na terenie Poznania po zakończeniu ośmiomiesięcznego sezonu ${ }^{25}$.

Bolesław Szczurkiewicz w czasie kilku miesięcy od przyjazdu do Poznania do momentu przejęcia teatru zdołał jednak powiększyć zespół Teatru Polskiego. Nowy dyrektor był postacią znaną w środowisku teatralnym, zasłynął przede wszystkim dzięki prowadzeniu wraz z żoną sceny w Wilnie. Kontakty w środowisku pozwoliły mu na zaangażowanie oprócz sił miejscowych szeregu artystów z Krakowa i Warszawy. Aktorzy ci, otrzymawszy pozwolenie na przyjazd od pruskich władz, przybywali w sierpniu i wrześniu do Poznania, o czym na bieżąco informowała prasa. W skład nowego zespołu aktorskiego, który rozpoczął pracę w sezonie 1918/19, wchodzili następujący artyści: Janina Biesiadecka, Maria Biskupska, Broniczowa, Zofia Czaplińska, Helena Czechowska, Maria Czerniakowa, Nuna Młodziejowska, Janina Pomorska-Lechowska, Maria Roszkiewiczowa, Józefa Wielgard, Ada Zawiejska, Helena Zaleska, Bracki, Zygmunt Biesiadecki, Kamiński, Kazimierz Kijowski, Władysław Konarski, Kajetan Kopczyński, Jan Kucharski, Tadeusz Lechowski, Stefan Lochman, Bolesław Rosiński, Franciszek Ryll, Marian Sosnowski, Leszek Stępowski, Władysław Stoma, Edward Topolski ${ }^{26}$. W trakcie trwania sezonu do zespołu dołączyli Włodzimierz Jewasiński i Janusz Strachecki. W lutym i w marcu 1919 r. Bolesław Szczurkiewicz wyjechał do Warszawy w celu angażowania nowych artystów. Przybyli wtedy do Poznania Józef Popławski i Bronisława Wojciechowska, a w maju wystąpili po raz pierwszy na poznańskiej scenie: Jadwiga Sachnowska, Eugenia Zasempianka, Alfred Szymański, Maksymilian Piotrowski, Wincent Nowakowski, Maria Dunikowska. W czasie sezonu odeszli na własne żądanie Helena Czechowska i Władysław Stoma ${ }^{27}$.

Zanim rozpoczęto sezon zimowy w Teatrze Polskim podwyższono ceny biletów. W „Kurierze Poznańskim” ukazało się pismo od „Dyrekcji Teatru Polskiego Tow. Akc.", podpisane przez Krysiewicza, Sczanieckiego i Rynarzewskiego, w którym Zarząd Spółki pisał: „Utrzymanie sceny i opłacanie liczniejszego personału [...] wymaga w obecnych ogólną drożyzną spo-

\footnotetext{
${ }^{25}$ M.K. Maciejewska, dz. cyt., s. 582.

26 „Kurier Poznański” 1918, nr 160, 188, 201, 217, 244.

27 „Kurier Poznański” 1918, nr 286, 1919, nr 41, 63, 122.
} 
wodowanych warunkach znacznie większych nakładów. Tych zwiększonych kosztów nie może pokryć przy obecnych cenach nasz teatr z powodu małych rozmiarów i dlatego przychylił się Zarząd »Teatru Polskiego « do wniosku Dyrekcji sceny do podwyższenia cen biletów o $20-25 \%$. Ceny podwyższone pobierać się będzie począwszy od inauguracyjnego przedstawienia rozpoczynającego sezon zimowy 1918/19". Zgodnie z uchwałą Spółki, ceny miejsc w Teatrze Polskim od początku sezonu zimowego wynosiły od pięćdziesięciu fenigów do sześciu marek ${ }^{28}$.

W miesiąc po inauguracji przeniesiono również kasę „zamawian” biletów. Dotychczas sprzedaż biletów prowadzona była w "magazynie instrumentów muzycznych i składzie nut St. Pełczyńskiego przy ul. Rycerskiej nr 40 narożnik ul. Berlińskiej”. Od 4 listopada 1918 r. decyzją dyrekcji przeniesiono ją do gmachu Teatru. Kasa otwarta była w godz. „od 10-1 przed poł. i 3-6 po pół" 29 .

Rozpoczęcie sezonu 1918/19 planowano na początek września 1918 r. Na inauguracyjne przedstawienie dyrekcja wybrała Kordiana Juliusza Słowackiego - po raz pierwszy mógł być wystawiony w Poznaniu. Miał w nim gościnnie wystąpić jeden z najwybitniejszych aktorów tamtego okresu - Michał Tarasiewic $z^{30}$. Nowo zaangażowani aktorzy nie byli jednak w stanie dojechać na czas z uwagi na utrudnienia ze strony władz pruskich. Artyści musieli miesiącami czekać na uzyskanie pozwoleń przyjazdu ${ }^{31}$. Rozpoczęcie sezonu odłożono więc na później. Teatr nie przestał jednak pracować i dawał przedstawienia bez przerwy wakacyjnej.

Inauguracja sezonu nastąpiła 4 października 1918 r. w piątek. W Kordianie w roli tytułowej wystąpił Bracki, dopiero 9 tego miesiąca zastąpił go występujący gościnnie Michał Tarasiewicz ${ }^{32}$. W niedzielę 6 października 1918 r. w kościele św. Marcina odbyła się msza św. na intencję rozpoczęcia sezonu zimowego w Teatrze Polskim ${ }^{33}$.

27 grudnia 1918 r. - kiedy padły pierwsze strzały rozpoczynające wybuch powstania wielkopolskiego - w Teatrze Polskim grano właśnie Betlejem Polskie Lucjana Rydla. Powstanie nie przerwało na dłuższy okres pracy sceny. Wiadomo na pewno, że zaplanowane na 28 grudnia przedstawienie ku czci Ignacego Paderewskiego z powodu walk ulicznych nie mogło się odbyćc ${ }^{34}$. Kiedy w grudniu 1918 r. w Poznaniu „wybuchła Polska”, jak się wtedy po-

28 „Kurier Poznański” 1918, nr 223, s. nlb.

29 "Kurier Poznański” 1918, nr 252, s. nlb.

30 „Kurier Poznański” 1918, nr 160, 205.

${ }^{31}$ Księga pamiatkowa miasta Poznania. Dziesięć lat pracy Polskiego Zarządu Stołecznego Miasta Poznania, Poznań 1929, s. 332.

32 Szerzej o premierze Kordiana pisze E. Guderian-Czaplińska, dz. cyt., s. 47-49.

33 „Kurier Poznański” 1918, nr 229, 234, 230.

${ }^{34}$ Księga pamiatkowa, s. 332. 
wszechnie mówiło, Teatr Polski działał już zorganizowany w przedstawiony powyżej sposób. Do końca sezonu 1918/19 nie zmieniło się nic w organizacji teatru.

Nowy okres w życiu Teatru Polskiego w wolnej Polsce przyniósł rok 1920. Nastąpiły wtedy dwie istotne zmiany. Pierwszą z nich było objęcie stanowiska współdyrektora Teatru Polskiego przez Romana Żelazowskiego.

Był to jeden $\mathrm{z}$ najwybitniejszych aktorów i reżyserów przełomu XIX i XX w. Urodzony w 1854 r., od wczesnej młodości związał się z teatrem. Już w czasach szkolnych organizował amatorskie przedstawienia, a pracę zawodową w teatrze rozpoczął w 1875 r., debiutując na scenie krakowskiej pod kierownictwem Stanisława Koźmiana. Reżyserował, grał i sprawował funkcję kierownika artystycznego w teatrze krakowskim w latach 1878-1883, 1889-1892, lwowskim 1886-1889, 1892-1898, 1919-1920 i Warszawskich Teatrach Rządowych 1899-1907. Przez cały okres wiele razy występował gościnnie na wielu polskich scenach, m.in. poznańskiej w sezonie 1877/78. Jako aktor największą sławę zyskał dzięki rolom bohaterskim i tragicznym. Jego interpretacje: Otella, Króla Lira i Ryszarda III, na stałe weszły do historii teatru polskiego. Zasłynął również jako wybitny reżyser ${ }^{35}$.

Żelazowski sprawował funkcje dyrektora Teatru Polskiego razem ze Szczurkiewiczem od początku sezonu 1920/ 21 do końca sezonu 1923/24. Był głównym reżyserem teatru i jego kierownikiem artystycznym. Pierwszymi przejawami jego działalności w Poznaniu były: reżyseria inauguracyjnego przedstawienia sezonu 1920/21 - Sarmatyzmu Franciszka Zabłockiego, oraz występ w Zasadzce Henriego Kistenmaeckersa. Artysta od razu zdobył bardzo wielkie uznanie poznańskiej krytyki. „Świetny w każdym calu” - napisano po jego pierwszym występie ${ }^{36}$. Jeszcze zanim objął kierownictwo dramatu, w prasie poznańskiej pisano o „kulturalnej misji”, jaką ma tutaj do spełnienia $^{37}$. To tutaj 17 marca 1924 r. obchodził swój złoty jubileusz pracy scenicznej, który zgromadził cały kulturalny Poznań w gmachu Teatru Wielkiego, „aby złożyć hołd i uwielbienie mężowi zasłużonemu”, jak napisano w "Kronice Miasta Poznania"38. Sam Żelazowski traktował swoją pracę w Poznaniu jako obywatelski obowiązek. Choć - jak pisał żartobliwie w swoim pamiętniku o przyjściu do teatru poznańskiego zadecydowały ostatecznie duchy, które na seansie spirytystycznym podpowiedziały mu, co ma wybrać (Żelazowski w 1920 r. otrzymał również propozycję objęcia teatru w Łodzi) ${ }^{39}$. Czesław Kędzierski napisał później: „Poznań miałby prawo i obowiązek uściskać owe

35 Stownik biograficzny teatru polskiego, s. 861; Wielkopolski stownik biograficzny, pod red. A. Gąsiorowskiego, J. Topolskiego, Warszawa-Poznań 1981, s. 733.

36 „Kurier Poznański” 1920, nr 194, s. nlb.

37 „Kurier Poznański” 1920, nr 105, s. nlb.

38 "Kronika Miasta Poznania” 1924, r. II, s. 62-63.

${ }^{39}$ R. Żelazowski, Pięćdziesiąt lat teatru polskiego. Moje pamiętniki, Lwów 1921, s. 68. 


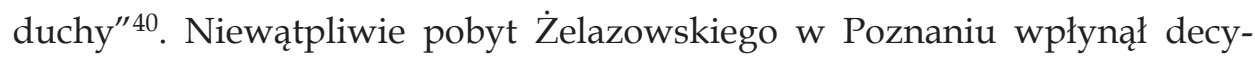
dująco na podniesienie poziomu artystycznego Teatru Polskiego. Owocem jego pracy był okres ambitnego repertuaru, wybitnej reżyserii i dobrego aktorstwa. Okres jego współdyrekcji z Bolesławem Szczurkiewiczem wydziela się z historii teatru jako jeden $\mathrm{z}$ najciekawszych artystycznie $\mathrm{w}$ historii teatru. Współdyrekcja Żelazowskiego i Szczurkiewicza trwała przez cztery sezony: 1920/21-1923/24. W 1924 r. Żelazowski opuścił Poznań, aby objać dyrekcję Teatru Narodowego w Warszawie ${ }^{41}$.

Kolejną zmianą $\mathrm{w}$ działalności Teatru Polskiego w pierwszych latach w wolnej Polsce była zmiana jego administracyjnego statusu.

Teatr Polski tylko przez półtora roku działał jako prywatne przedsiębiorstwo zarządzane przez Spółkę Akcyjną Teatr Polski w Ogrodzie Potockiego w Poznaniu, w której imieniu dyrektor Szczurkiewicz sprawował kierownictwo od 20 sierpnia $1918 \mathrm{r}$.

Po zakończeniu sezonu 1918/19 dyrekcja zdecydowała się na otwarcie w Teatrze Polskim działu operetkowego. Stworzono nowy, odrębny zespół operetkowy, do którego zaangażowano "szereg znanych sił artystycznych i cały zespół chórowy”. Kierownictwo nad nim objął Feliks Kochański - „znany kapelmistrz". W związku z tym powiększono orkiestrę do 26 osób. Sezon operetkowy otwarto 14 sierpnia 1919 r. przedstawieniem Polska krew Oskara Nedbala, które zgromadziło liczną publiczność ${ }^{42}$. Inauguracja sezonu dramatycznego nastąpiła w dwa tygodnie później, 28 sierpnia, wystawieniem komedii Aleksandra Fredry Damy i huzary. Wprowadzenie działu operetkowego $\mathrm{w}$ teatrze podyktowane było względami finansowymi. Przedstawienia operetkowe gromadziły zawsze liczną publiczność i długo nie schodziły z afisza, zasilając kasę teatru. Wraz z rozpoczęciem nowego sezonu w prowadzono kolejną podwyżkę biletów o pięćdziesiąt proc., motywując ją podwyższeniem pensji i gaż personału teatralnego oraz wzrostem kosztów eksploatacji ${ }^{43}$. Nie zakończyło to jednak kłopotów finansowych Teatru Polskiego w sezonie 1919/20. W pierwszych miesiącach roku $1920 \mathrm{w}$ prasie pojawiły się informacje świadczące o złym stanie finansowym teatru. W lutym wybuchł strajk orkiestry teatralnej z powodu niskiej gaży miesięcznej. Nawet redakcja „Kuriera Poznańskiego" życzyła jej członkom polepszenia warunków bytu ${ }^{44}$. Kilka dni później podczas posiedzenia Rady Miejskiej odrzucono „wniosek artystów Teatru Polskiego o zwolnieniu tegoż teatru od wyższych podatków" ${ }^{\prime 4}$. Strajk orkiestry po dwóch dniach, „po wzajemnych ustępstwach” został zakończo-

\footnotetext{
40 „Kurier Poznański” 1922, nr 27, s. 3.

41 „Kronika Miasta Poznania” 1924, r. II, nr 7/8, s. 159.

42 „Kurier Poznański” 1919, nr 178, 199, s. nlb.

43 „Kurier Poznański” 1919, nr 181, s. nlb.

44 „Kurier Poznański” 1920, nr 39, s. nlb.

45 „Kurier Poznański” 1920, nr 42, s. nlb.
} 
ny"46, ale dyrekcja zmuszona została do wprowadzenia kolejnej podwyżki cen biletów w marcu 1920 r. Tym razem zespół aktorski zwrócił się do kierownictwa z żądaniem przyznania im dodatku drożyźnianego, „zwłaszcza, że personał techniczny i członkowie orkiestry dwukrotnie już uzyskali taki dodatek [...], a dyrekcja teatru, uznając za słuszne żądania artystów, uwzględniła je, aby zapobiec daleko idącym nieporozumieniom". Motywując podwyżkę cen, pisano jeszcze: „Trudne warunki finansowe w jakich istnieć musi ten o własnych siłach utrzymujący się teatr (opłacający $\mathrm{w}$ dodatku niemal szóstą część od swoich dochodów na korzyść miasta) zmuszają do nieznacznego podwyższenia ceny miejsc wyłącznie tylko na przedstawienia operetkowe. Ceny dramatu z wyjątkiem premier pozostaną bez zmian" 47 .

$\mathrm{Na}$ złą finansową sytuację teatru wpływała zła sytuacja gospodarcza odbudowującego się kraju. Z podobnymi kłopotami borykał się Teatr Wielki powołany do życia w sierpniu 1919 r. przez władze polskie po przejęciu z rąk niemieckich gmachu niemieckiej Opery ${ }^{48}$. Teatr Wielki finansowany był przez Zarząd Miasta, ale był placówką deficytową - koszty jego działalności wynosiły dwa mln trzysta tys. mk, z czego znaczną część subwencjonowało miasto ${ }^{49}$. W sezonie 1919/20 dwukrotnie wybuchały tam strajki zespołu artystycznego i orkiestry operowej ${ }^{50}$. Deficytowa w Teatrze Wielkim była działająca tam obok działu muzycznego scena dramatyczna, która nie przyciągała publiczności nie tylko z uwagi na gust poznańskiej publiczności preferującej repertuar operetkowy i komediowy, ale również ze względu na niski poziom artystyczny dawanych tam przedstawień ${ }^{51}$. W konkurencji dwóch scen dramatycznych Teatr Polski zdecydowanie wygrywał.

Kłopoty finansowe obu teatrów poznańskich stały się przyczynkiem do podjęcia przez Magistrat kroków w celu przejęcia w zarząd miasta obu teatrów i połączenia ich scen dramatycznych. Na posiedzeniach Rady Miejskiej w czerwcu 1920 r. dwa razy dyskutowano wniosek o połączenie obu scen dramatycznych pod zarządem miasta. Popierał go m.in. prezydent miasta Jarogniew Drwęski. 23 czerwca 1920 r. w głosowaniu przyjęto wniosek Magistratu. Teatr Polski i Teatr Wielki stały się teraz jedną jednostką administracyjną, tworząc tzw. Teatry Miejskie ${ }^{52}$. Magistrat $\mathrm{m}$. Poznania przejął wszystkie prawa i obowiązki wynikające z kontraktu dzierżawy gmachu Teatru Polskiego, m.in. opłacanie czynszu dzierżawnego Spółce Akcyjnej Teatr Polski w Ogrodzie Potockiego w Poznaniu, oraz prowadził teatr na własny ra-

\footnotetext{
46 „Kurier Poznański” 1920, nr 41, s. nlb.

47 „Kurier Poznański” 1920, nr 52, s. nlb.

48 T. Świtała, Opera Poznańska 1919-1969, Poznań 1973, s. 9.

49 „Kurier Poznański” 1920, nr 137, 143, s. nlb.

50 T. Świtała, dz. cyt., s. 11.

51 „Kurier Poznański” 1920, nr 192, s. nlb.

52 „Kurier Poznański” 1920, nr 137, 143, s. nlb.
} 
chunek, finansując go ze swojego budżetu ${ }^{53}$. Od sezonu 1920/21 Teatr Polski po raz pierwszy od jego założenia przestał być prywatnym przedsiębiorstwem, a stał się teatrem miejskim.

Przejęcie Teatru Polskiego w zarząd miasta diametralnie zmieniało jego sytuację. W trudnych powojennych warunkach finansowanie sceny przez miasto zapewniało jej dalszy rozwój na określonym poziomie, czego prawdopodobnie nie zdołano by utrzymać, prowadząc teatr prywatnie. Dowodem tego mogą być poprzednie lata historii poznańskiej sceny, w której często warunkiem utrzymania sceny była rezygnacja z wysokiego poziomu artystycznego.

W pierwszym sezonie działalności Teatru Polskiego pod opieką miasta w poznańskiej scenie zaszły kolejne zmiany, gwarantujące podwyższenie poziomu repertuaru teatru.

Opieka władz miejskich zapewniła Teatrowi Polskiemu możliwość rozwoju przede wszystkim przez połączenie ze sceną dramatyczną Teatru Wielkiego. Wraz z rozpoczęciem sezonu 1920/21 bowiem powiększonemu zespołowi aktorskiemu Teatru Polskiego oddano scenę Teatru Wielkiego na dwa wieczory w tygodniu ${ }^{54}$. Większa scena dawała możliwość wystawiania sztuk tzw. wielkiego dramatu, których przedstawiania w gmachu przy ul. 27 Grudnia nie można było podjąć z uwagi na małe jego rozmiary. Taka możliwość zapewniała ambitniejszy repertuar.

Przejęcie Teatru Polskiego przez miasto zapewniło jeszcze jedną zmianę w działalności sceny, której efektem było podwyższenie artystycznego poziomu teatru. Było to objęcie współdyrekcji teatru przez Romana Żelazowskiego, co przedstawiłam powyżej. Należy w tym miejscu dodać, że jego przyjazd do Poznania był wynikiem działań Magistratu m. Poznania. Żelazowski przebywał w Poznaniu już w maju 1920 r. w związku z przejęciem kierownictwa dramatu w Teatrze Wielkim, który już wtedy zarządzany był przez miasto ${ }^{55}$. Połączenie scen dramatycznych Teatru Wielkiego i Polskiego zapewniało jego współpracę Teatrowi Polskiemu.

Przekształcenie Teatru Polskiego z prywatnego przedsiębiorstwa w teatr miejski przyniosło wiele korzyści poznańskiej scenie na płaszczyźnie artystycznej. Wprowadzone innowacje nie były jednak w stanie zapobiec kłopotom finansowym teatru. Teatr Polski wchodził w skład Teatrów Miejskich i był rozliczany razem z Teatrem Wielkim. Od początku okresu finansowania teatrów przez miasto Magistrat finansował ich ciągły deficyt. W 1920 r. wynosił on 6,55 proc. budżetu, w 1921 - 6,3 proc., a w $1922-8,2$ proc. ${ }^{56} \mathrm{~W}$ lutym

\footnotetext{
53 APP, AmP, nr 3567, k. 132.

54 APP, AmP, nr 3604, k. 428.

55 „Kurier Poznański” 1920, nr 105, s. nlb.

56 „Kurier Poznański” 1923, nr 133, s. 4.
} 
1923 r. Rada Miejska uchwaliła wniosek Magistratu o zaciągnięcie pożyczki z Krajowej Kasy w wysokości stu mln mk na pokrycie deficytu Teatrów Miejskich, które wykazały one w po pierwszych czterech miesiącach w sezonie 1922/2357. W 1923 r. w obliczu narastającego kryzysu gospodarczego władze miejskie zmuszone były podjąć kroki ograniczające wydatki na finansowanie Teatru Polskiego i dramatu w Teatrze Wielkim. Od marca do czerwca działalność Opery i Teatru Polskiego pod zarządem miasta stała pod znakiem zapytania. Posiedzenie Rady Miejskiej 28 lutego 1923 r. w całości poświęcone było „naprawie gospodarki teatralnej”. W czasie burzliwej dyskusji padały wnioski o zamknięciu obu instytucji. Ogromne sumy wydawane przez magistrat na finansowanie teatrów budziły sprzeciw wielu radnych wobec sytuacji, w której miasto musiało uporać się z bardziej palącymi problemami (np. zagrożenie głodem wielu bezrobotnych rodzin). Przewidywano, że przy dalszym „wzroście drożyzny” niedobory w deficycie obu scen sięgną od połowy do miliarda mk. Padały stwierdzenia, że Teatr Polski prowadzony jest oszczędniej niż w poprzednim sezonie, a głównym powodem deficytu są nadmierne gaże - samej dyrekcji wynosiły trzynaście mln. W lutym 1923 r. Rada Miejska postanowiła nie odnawiać kontraktu z dyrekcją Teatru Polskiego. Magistrat miał prowadzić dramat jedynie do końca bieżącego sezonu. Jak podawał „Kurier Poznański”, podjęte uchwały spowodowane były głównie troską o obywateli, którym groził głód ${ }^{58}$.

Decyzja Rady Miejskiej z lutego 1923 r. wzbudziła zdecydowany sprzeciw w niektórych poznańskich kręgach społecznych. Już 12 marca $1923 \mathrm{r}$. w „Kurierze Poznańskim” ukazała się odezwa nowo powstałego Komitetu Doraźnej Pomocy Teatrom Miejskim, w której, odwołując się do narodowych i ideowych uczuć Polaków, nawoływano do jednorazowej składki na rzecz teatrów odciążającej wydatki miasta. Na czele komitetu stali: dr Łucjan Kamieński, dr Leon Surzyński, Feliks Chrzanowski, a wśród jego członków znaleźli się m.in.: prof. dr Heliodor Święcicki, prof. dr Jan Rutkowski i inni dziekani wydziałów Uniwersytetu Poznańskiego, a także Zdzisławowa ks. Czartoryska, dyrekcja Związku Obrony Kresów Zachodnich oraz redakcje pism poznańskich ${ }^{59}$. Już wkrótce do akcji pomocy teatrom przyłączyli się sami artyści, którzy na ogólnym zebraniu „oświadczyli gotowość złożenia ofiary na rzecz ratowania teatrów". Rodzaj i zakres tej ofiarności miały uchwalić poszczególne działy podczas zebrań ${ }^{60}$. Akcje, mimo że nagłośnione przez poznańską prasę, nie przyniosły jednak oczekiwanego rezultatu. W „Kurierze Poznańskim” w rubryce Składki i pokwitowania tylko dwa razy

\footnotetext{
57 „Kurier Poznański” 1923, nr 31, s. 5.

58 „Kurier Poznański” 1923, nr 49, s. 4.

59 „Kurier Poznański” 1923, nr 58, s. 8.

60 „Kurier Poznański” 1923, nr 69, s. 6.
} 
ukazały się adnotacje darowizn przeznaczone na Teatry Miejskie. Po sto tys. mk na Operę Poznańską złożyli: firma Wiza i Małuszek z ul. Nowej ${ }^{61}$ oraz Stefania Wolniewiczówna i Tadeusz Wolniewicz ${ }^{62}$. Razem zebrano trzysta tys. mk, podczas gdy przewidywany deficyt teatrów w czerwcu szacowano już na dwa mld $\mathrm{mk}^{63}$. W czasie zaborów nie raz wspomagano teatr składkami pieniężnymi, teraz „Kronika Miasta Poznania” napisała: „Akcja składkowa na rzecz teatrów okazała się bezskuteczną" 64 .

Po uchwale Rady Miejskiej z 28 lutego 1923 r. sprawa Teatru Polskiego przycichła na jakiś czas, by powrócić na łamy prasy w maju. Wtedy ukazała się odezwa Poznańskiego Związku Artystów Scen Polskich, skierowana do „Sfer Decydujących z najgorętszym apelem, aby zechciały raz jeszcze rozważyć i w duchu kultury załatwić tę ważną sprawę narodową" ${ }^{65}$. Z notki z „Kuriera Poznańskiego” z 14 czerwca 1923 r. wynika również, że w sprawie Teatru Polskiego dwukrotnie zebrali się przedstawiciele świata naukowego, literackiego i artystycznego oraz władz miejskich Poznania. Na spotkaniach tych ustalono „zgodny pogląd, [...] że teatr dramatyczny musi pozostać w ręku miasta, musi dawać gwarancję, że nie nastąpi w nim obniżenie pozio$\mathrm{mu}^{\prime \prime 66}$. Na ostatnim posiedzeniu Rady Miejskiej w sprawie Teatrów Miejskich dyskusja w ich sprawie zajęła prawie trzy godziny, "gorąca, namiętna i nader wyczerpująca". Wyrażono w niej uznanie dla Bolesława Szczurkiewicza. Prezydent Drwęski powiedział: „Mamy wspaniałego dyrektora”, i to prawdopodobnie dzięki jego przemówieniu, zakończonemu hasłem: „Miasto sobie!", głosowanie w sprawie utrzymania Teatru Polskiego w zarządzie miasta zakończyło się pomyślnie. 13 czerwca 1923 r. Deputacja Teatralna Magistratu uchwaliła "prowadzić nadal oba teatry we własnym zarządzie przy zaprowadzeniu wszelkich oszczędności, rewizji kontraktów, redukcji personelu, orkiestry, baletu i zniesienia wielkiego dramatu" ${ }^{\prime 67}$.

Teatr Polski działał jako część Teatrów Miejskich pod opieką miasta bez wystawiania na scenie wielkiej do 1930 r. 14 maja tegoż roku Rada Miejska uchwaliła wniosek o oddaniu Teatru Polskiego Spółce Akcyjnej Teatr Polski, która prowadziła go we własnym zarządzie od 1 września 1930 r. ${ }^{68}$

Pierwsze lata historii Teatru Polskiego w wolnej Polsce przyniosły kilka zmian organizacyjnych $\mathrm{w}$ jego działalności. Dwie zmiany dyrekcji w sierpniu 1918 r. (objęcie tego stanowiska przez Bolesława Szczurkiewicza)

\footnotetext{
61 „Kurier Poznański” 1923, nr 69, s. 9.

62 „Kurier Poznański” 1923, nr 75, s. 7.

63 „'Kurier Poznański” 1923, nr 133, s. 4.

64 „Kronika Miasta Poznania” 1923, r. I, nr 7, s. 142.

65 „Kurier Poznański” 1923, nr 119, s. 6.

66 „Kurier Poznański” 1923, nr 132, s. 6.

67 „Kurier Poznański” 1923, nr 133, s. 4.

68 APP, AmP, nr 3606, k. 34.
} 
i w 1920 r. (zatrudnienie Romana Żelazowskiego jako współdyrektora), oraz przejście pod zarząd miasta wpłynęły znacząco na rozwój sceny. Już dwa pierwsze powojenne sezony pod wyłącznym kierownictwem Szczurkiewicza ożywiły życie teatralne miasta i podniosły Teatr Polski z upadku. Przybycie Żelazowskiego podniosło jeszcze bardziej jego poziom, a opieka miasta od 1920 r. zapewniła Teatrowi byt $\mathrm{w}$ trudnych nieustabilizowanych warunkach odbudowującego się kraju. Działalność i praca dyrektorów Teatru Polskiego w latach 1918-1924 sprawiły, że okres ten jest uznawany za jeden z najciekawszych w historii tego teatru.

\section{Bibliografia}

Akta miasta Poznania (Archiwum Państwowe w Poznaniu).

Baniewicz E., Teatr poznański w latach 1908-1918, [w:] Dzieje teatru polskiego, red. T. Sivert, t. IV: Teatr polski w latach 1890-1918, Warszawa 1987.

Dzieje teatru polskiego, red. T. Sivert, t. III: Teatr polski od 1863 roku do schytku XIX wieku, Warszawa 1982.

Dzieje teatru polskiego, red. T. Sivert, t. IV: Teatr polski w latach 1890-1918, cz. 1: Zabór pruski i austriacki, Warszawa 1987.

Guderian-Czaplińska E., Teatralna Arkadia. Poznańskie teatry dramatyczne 1918-1939, Poznań 2004.

Grzymała-Siedlecki A., Świat aktorski moich czasów, Warszawa 1957.

Koller J., Nuna Młodziejowska-Szczurkiewiczowa, „Gazeta Poznańska” 1958, nr 27.

Koller J., Gawędy teatralne, Poznań 1962.

„Kronika Miasta Poznania” 1923, r. I, nr 7.

„Kronika Miasta Poznania” 1924, r. II, nr 7/8.

Ksiegga pamiątkowa miasta Poznania. Dziesięć lat pracy polskiego Zarządu Stołecznego Miasta Poznania, Poznań 1929.

„Kurier Poznański” 1918-1924; 1933, nr 443.

Maciejewska M.K., Teatr Polski w Poznaniu w latach 1912-1914, [w:] Prace o literaturze i teatrze ofiarowane Zygmuntowi Szweykowskiemu, Wrocław 1966.

Młodziejowska-Szczurkiewiczowa N., Kartki z niedokończonego pamiętnika, [w:] Poznańskie wspominki. Starzy poznaniacy opowiadaja, Poznań 1960.

Noskowski W., Trochę wspomnień o Szczurkiewiczu, „Kurier Poznański” 1933, nr 443.

Stownik biograficzny teatru polskiego 1765-1965, red. Z. Raszewski, Warszawa 1973.

Świtała T., Opera Poznańska 1919-1969, Poznań 1973.

Witkowski M., Teatr w Poznaniu 1863-1896, [w:] Dzieje teatru..., t. III: Teatr polski od 1863 do schytku XIX wieku, Warszawa 1982.

Żelazowski R., Pięćdziesiąt lat teatru polskiego. Moje pamiętniki, Lwów 1921. 
Monika Nawrocka-Theus

\title{
Pierwsze lata wolności w Teatrze Polskim w Poznaniu (1918-1924)
}

\begin{abstract}
Streszczenie
Artykuł ukazuje pierwsze lata działalności Teatru Polskiego w Poznaniu po odzyskaniu wolności. Był to okres dyrekcji Bolesława i Nuny Szczurkiewiczów, którzy zajęli się organizacją sceny poznańskiej już w kwietniu 1918 r. Na podstawie dokumentów oraz doniesień z prasy poznańskiej w artykule opisano, w jaki sposób w latach 1918-1924 Szczurkiewiczowie rozwiązywali kwestie formalne działalności Teatru, formowali zespół aktorski i przygotowywali się do otwarcia nowego sezonu. W 1920 r. do dyrektorskiej pary dołączył Roman Żelazowski i dzięki ich wspólnej pracy lata 1920-1924 były jednym z najciekawszych okresów historii Teatru Polskiego w Poznaniu.
\end{abstract}

\section{Old Polish archival practice based on the royal treasury and archive of Kraków $\left(16^{\text {th }}-18^{\text {th }}\right.$ centuries). Inventory commissions}

\begin{abstract}
The article describes the first years of operation of the Polish Theater in Poznan after regaining independence. This was the time when the directors were Bolesław and Nuna Szczurkiewicz, who organized the stage in Poznan as early as April 1918. The article describes how in the years 1918-1924, the Szczurkiewicz couple solved formal problems of the Theater's operation, chose actors and prepared for the new season openings, based on the documents and information found in the Poznań press. In 1920, Roman Żelazowski joined the couple. Owing to their joint effort, the years 1920-1924 became one of the most interesting periods in the history of the Polish Theater in Poznań.
\end{abstract}

